\title{
'Political Leadership and the Politics of Performance: France, Syria and the Chemical Weapons Crisis of 2013'.
}

\begin{abstract}
This article draws upon developments in UK research on political rhetoric and political performance in order to examine the incident in 2013 when French President François Hollande committed French forces to a US-led punitive strike against Syria, after the use of chemical weapons in a Damascus suburb on 21 August. The US-led retaliation did not take place. This article analyses Hollande's declaration on 27 July and his TV appearance on 15 September. His rhetoric and style are best understood as generic to the nature of the presidential office of the Fifth Republic. The article concludes by appraising how analysis of the French case contributes to the developing literature on rhetoric, celebrity, and performance.
\end{abstract}

Keywords: François Hollande, political performance, rhetoric, Syria

This article takes what is an emerging body of literature in UK political science on political performance and celebrity politics, and applies it to France's presidential foreign policy initiative in 2013, namely, François Hollande’s decision to join with the Americans in a military strike against Bashar AlAssad's Syria in the wake of Assad's alleged use of chemical weapons against civilians in Ghouta, near Damascus, on 21 August 2013. The US/French attack upon Assad never took place. We shall demonstrate three things related to President Hollande's 'performance' of presidential leadership: first, that Hollande's foreign policy decision was driven by domestic political issues related to his personal image; second, that presidential comportment is framed by the perceived public exigency of a highly personalised presidential 'character' or 'persona' which must be seen to perform and act effectively and decisively; and third, how the performance or performances were made rhetorically, in an effort to project just such a highly personalised presidential persona. We shall also argue that the French decision on Syria was a foreign policy mistake, even in its own terms and in two related ways, in that it had the opposite to its intended effect, namely, that it made Hollande seem powerless and indecisive; and it threw into relief the limited reach of the French 
presidency in the international arena. This unsuccessful political performance was partly related to choices made. Over and above this, however, it also points to an arguably dysfunctional element in the Fifth Republic in which the central political actor in the regime is encouraged, obliged even by the political system itself to make consequential displays of personal boldness and self-assertion to doubtful political purpose. The root cause of the Syria policy decision was the desire to demonstrate presidential initiative, which it failed to do.

From early in his presidency, from the summer of 2012, Hollande's popularity ratings had been falling relentlessly until, by mid-2013, he had an $80 \%$ disapproval rating, the worst and fastest fall of any President of the Fifth Republic. Much of his unpopularity was linked to perceptions of his character as well as to the policies or perceived inaction of his government. He was seen as indecisive, undynamic, incompetent, and unpresidential. His popularity slide had slowed briefly when he took the decision in January 2013 to intervene in Mali. Foreign policy initiatives had often been associated with the Presidents of the Fifth Republic. Fifth Republic foreign policy has not been that different in its aims from Fourth Republic foreign policy (Cerny 1980; Hoffman 1994). One can identify certain changes of emphasis: Middle East policy, for example. But what distinguishes the foreign policy of the Fifth Republic is the style and tone that has driven it forward. De Gaulle’s accession to power in 1958 (particularly after 1962, when he embedded 'his' republic by pushing through the election of the President by direct adult suffrage, thus making the presidency institutionally 'popular') meant that as he stepped up on to the international stage to engage in 'grandes querelles', only one type of foreign policy was possible: grandiose assertions of France's greatness, civilizing mission, and 'rang', and a pretention to European leadership (Berstein 2001; Chalaby 2002; Gaïti 1998).

The evolution of relations inside the European Union and efforts, from Georges Pompidou onwards, at 'concertation' (a process begun incrementally as soon as 
de Gaulle left office) saw the re-entry of France into the 'grain' of European diplomacy overall. But the thrust of both European and wider foreign policy, reflecting the paradigmatic claims of Fifth Republican leadership, has been a long-term illustration of what we might call path-dependent narcissism, a perpetual temptation to use France's foreign policy 'interests' to personal presidential purpose. And because of the symbolic politics that surrounds the presidency, the President is implicated in all aspects of policy, both 'high' and 'low'; and with a parliamentary majority has power in all areas. This high/low duality would be significant in this case, as we shall illustrate. The French presidency stands alone amongst its allies in needing no parliamentary approval to take military action of this type, which lends to it the character of individual self-assertion. Hollande, however, had no foreign policy experience before taking office. Linked to this, was a general unfamiliarity with the United States. France had had markedly poorer relations with the US than its European counterparts, and this at least since de Gaulle's withdrawal from the NATO command structure in 1967. Relations with the US had been improving over the recent period, and Hollande's decision over Syria was an ill-informed assertion of that. We say ill-informed because a more informed knowledge of the United States would have allowed Hollande to see that the American administration did not actually want to attack Syria - a point the Russians realised to their own great advantage. We can speculate that every other French President: de Gaulle, Pompidou, Giscard, Mitterrand, Chirac, and Sarkozy would have been more aware of the diplomatic potential of keeping Russia in the frame. We can, therefore, make an initial remark that the French presidency, by institutionally allowing for presidential scope, automatically increases the possibility of individual mistakes.

Hollande's decision over Syria, therefore, should be seen in the two contexts of the evolution of France/US relations and the evolving context of the Fifth 
Republic. Evolving means here, however, not just evolving norms and constraints but a continuous stream of presidential initiatives which, unlike in the UK, for example - the action against Syria being a case in point - are not subject to parliamentary or governmental caution. This makes the French case an exemplar of personalised political performance in political science. Let us then: look at the epistemological issues surrounding political performance in the French Fifth Republic, give a brief chronology of events, and then examine, performatively and rhetorically, how President Hollande both performed his personal initiative, and then performed, as it were, its failure. We shall then conclude by examining what the sequence of events reveals about presidential performance in the French regime.

\section{Theoretical Context: Rhetoric, Persona, and Celebrity Politics}

A growing body of mainly UK research over the past decade has identified the significance and consequences of the performing 'celebrity' politician. What we wish to demonstrate here is how appropriate such research is to the French case, dramatically so given the prevailing institutional and cultural conditions which we shall elaborate below. Finlayson (2002) has analysed the performance of Tony Blair, through style, appearance and language. He analyses a range of party broadcasts (1994-2001) and demonstrates the personalised populism displayed and mobilised through the construction of the 'character', Tony Blair. The character is performed essentially through his discourse, rhetoric, and image. For Martin (2013), a political speech is a dynamic medium for mobilising ideas as a form of action. Martin sets out a rhetorical approach to political strategy which analyses the rhetorical context, the rhetorical argument, and rhetorical effects. Corner (2000) has argued that 'political personhood' is projected in three ways: iconically (e.g. photo opportunities); vocally (e.g. an increasing self-referentiality in public address); and kinetically (e.g. presidential announcements). Cumulatively, the iconic, vocal and kinetic enhance the 
'personal' within political culture and institutions, each offering opportunities and constraints for the use of persona to have political effect. Street (2004; 2012) argues that the celebrity politician is no longer an exceptional form of political representation, but rather is characteristic of the nature of political representation generally. This will be particularly significant in Hollande's case as he was elected in 2012 initially - against the flamboyant Nicolas Sarkozy on a claim to non-celebrity, and a commitment to end such politics. Wheeler (2012) builds upon Street's research and asks to what extent celebrity politicians can 'input' aggregated forms of 'agency' to affect political outcomes. New forms of technology have altered the relationship between politicians and audiences and created imagined proximity to and, we would argue, imagined distance from leadership actors which alter the 'pace' and add to the complexity of the relationship. Research by Drake and Higgins (2012) combines political language, mediated performance and celebrity. They reconceptualise celebrity as a process or a frame, as opposed to a quality that individuals possess; a celebrity frame has performative and interpretative rules through which media publics are configured and addressed. The presidential configuration and its forms of address lend themselves to ostentatious selfassertion. Gaffney and Lahel have used this growing body of UK research and applied it to the political performance of the leader of the UK Labour Party, Ed Miliband, in the 2010-2015 period (Gaffney and Lahel 2013a; 2013b). Through Miliband's rhetorical performance, they identified the function of the 'personalised political' and how it expressed and put to use (in order to change the party's narrative) the character of the speaker/performer. What we shall do in this article is show how the emphasis and findings of this developing body of research in the UK is even more appropriate to the overtly personalised French Fifth Republic. François Hollande began his presidency attempting to depersonalise and alter the general evolution of the presidential regime, but in a confused way which we have analysed elsewhere (Gaffney 2015, forthcoming). 
As his popularity began seriously to fall, he reverted to a highly personalised style, realigning himself with what we shall call the 'performative presidency' (Gaffney 2014), and the assumption that foreign policy lends itself concertedly to the projection of a heroic and decisive political persona. It is all the more startling, therefore, that the creative thrust of research on the French presidency and political leadership more generally has also taken place outside France.

The emerging UK literature is doubly informative because in France, there is little literature to review. We are concerned with establishing a place for the study of leadership and rhetorical performance and their relationship to institutions (including the media), to political culture and to culturally fashioned audience reaction. And yet in French political science the study of contemporary rhetoric is limited, even less so the sub-discipline study of leadership rhetoric. What does exist, however, but which ultimately militates against the study of presidential performance, is discourse analysis. Rhetoric as a discipline declined because of changes in how language itself was perceived (and, negatively, how rhetoric was perceived). Developing from Saussurean linguistics (Saussure, 1995), enquiry focused on the system (langage) expressing itself through parole (speech). One of the most thoroughgoing revisions of the study of language was the development from the 1950s (drawing explicitly upon Saussurean linguistics) of French Structuralism. In the field of linguistics, its essential effect and purpose was to demonstrate that people do not use language, language uses people. The extension of linguistic study in the social sciences saw a radicalisation of this approach through the development in the 1970s and 1980s of discourse analysis and then from the 1990s, critical discourse analysis (CDA) in France and elsewhere, especially the UK. There has been a lot of interesting work (Wodak, 2009; van Djik, 2008; Fairclough, 2014) but the overall Saussurean structure remains and is adapted in order to demonstrate not only how speech (parole) mediates language, but how 
parole mediates power relations in society. This approach was heavily influenced from the 1950s onwards by Marxism and by semiology, the result being that the function of the analysis of language was to reveal the underlying structures of ideology (Barthes 1957). Discourse analysis colonised the study of language. Interest in rhetorical performance and agency were, therefore, minimal. Hence the dominance of journals such as Langages, Langage et société, and Mots. There has also been in France a preponderance of a quantitative type of analysis of the kind 'The Vocabulary of...' (Cotteret 1969, Labbé 1977; 1990). ${ }^{\mathrm{i}}$

The United States has a thriving rhetorical studies tradition, its most influential researcher since the 1980s is Kathleen Hall Jamieson who, with others, redefined the study of leadership rhetoric as it moved through its classical period (1940-1970) into the Reagan and post-Reagan eras, the 'Electronic Age' (Hall Jamieson, 1988). As regards presidential rhetoric, much of this scholarship focuses upon 'Presidents creating the Presidency' (Kohrs Campbell and Hall Jamieson, 2010). In this way, a lot of its emphasis is 'performative' in the Austinian sense (Austin, 1975): by speaking, the President becomes the presidency (and vice versa). However, we should stress that although concerned with the performative, the US research is overwhelmingly American. This may seem obvious, but it means not only that US rhetorical studies focus on the generic (how the President 'performs' the US presidency), but that the institutional, cultural, and other frameworks are also national specific, and in our study here, it is the French character of the institutions and culture and their relationship to agency we wish to highlight.

In the related area of political leadership studies, it is also worth noting that the general thrust of these are not French either, the best focusing on the institutional conditions of leadership and its scope (Elgie 2011; Helms 2012). The reason for this further deficiency in the French literature is due simply to 
the dominance of constitutionalist approaches to the presidency (Duhamel 1993). This led French scholarship for decades to stress almost exclusively understanding the presidency in terms of the distribution of powers between it and the National Assembly. Our interest, in contrast, is to identify the institutions as the condition of performance along with the culture that informs them (e.g. the providential leader in the French 'imaginaire'), and their history (e.g. developments in presidential style since 1958); and then to identify the agency of performance through rhetoric, and to appraise its success as performance.

De Gaulle's real contribution to French politics was to organise the political institutions in such a way as to give a constitutional framework to the arguably unconstitutional idea that the leader's true function was to give rhetorical expression to the idea that the President's relationship was with an imagined idea of France, and that this accorded to the office-holder exclusive decisionmaking powers. The providential leader knows what to do, because he can 'envision' the truth, realities, dangers, the way forward, and 'see' the future in a way that others cannot (Garrigues 2012). This is why he can - and must - take decisions on his own. This was to have far-reaching consequences for the evolution of the Fifth Republic, yet has been singularly unresearched in French scholarship (Bell and Gaffney 2013). The Fifth Republic is best understood as the performance of a particular kind of leadership within a particular configuration of institutions, themselves embedded within an influential political culture.

The virulent myth of the providential leader was used by de Gaulle to defeat the Fourth Republic (1946-1958), but then became locked into it by the institutions of the Fifth Republic, conferring on the President the expectation, if not indeed the obligation, to create and justify policy decisions as personal decisions. Since the early 2000s, a new phenomenon has emerged, namely celebrity politics, 
where the whole area of the President as the literal and metaphorical embodiment of politics takes on new forms. It is clear that much of the criticism of Nicolas Sarkozy's presidency (2007-2012) was that he diminished the office by giving it a 'bling' aspect and, as we have already noted, Hollande used public hostility to this as a campaign strategy. Hollande soon found, however, that being a celebrity - of one kind or another - was now one of the requisites of the office.

This means that the French President more than, say, any UK politician, even a Thatcher or a Blair, is 'on stage' permanently. This literally 'dramatic' quality of the Fifth Republic is, therefore, part of the culture because it is institutionally maintained. This will throw into relief the perceived relationship of individuals to events, and perceptions of individuals as solutions to difficult events. In fact, we can take the reasoning a stage further. We shall see in the case of the chemical weapons crisis that - however real the events were - the Syrian crisis is constructed in French political rhetoric by the French presidency, with Hollande projected as the protagonist of a heroic narrative. The performative scope of the presidency reaches well beyond its constitutional provision. Rather, it is a question of how the institution is rhetorically constructed and performs. Paradoxically, therefore, the Fifth Republic allows for enormous creativity but is also, through bad performance, or the absence of effective performance, more volatile, and the consequences of performance less predictable.

\section{Brief chronology of the events}

There is an irony in the fact that America's oldest ally (Secretary of State Kerry's term), France, became momentarily its newest in 2013 when it became clear that France was the US' only significant ally in the threat of military action against the Syrian regime. An irony in that it was not really true; rather, a diplomatic accident, born of David Cameron's hurried and unsuccessful attempt 
on 30 August in the UK House of Commons to get backing for military action against Syria in the wake of the chemical weapons attack. If it had been true, France might have been more cognizant of America's underlying reluctance to commit to military action in this case. ${ }^{\text {ii }}$ After the shock of the UK's vote against, President Obama decided to consult the US Congress in order to maintain legitimacy and gain time. He referred to the UK's role, but made no reference to France at all. As a result of both Cameron and Obama asking for parliamentary approval, the French were left isolated internationally and in political disarray domestically from the outset.

The aggressive stance by Hollande which we shall examine below reflected intensely the highly personalised nature of the Fifth Republic regime itself, as if France 'possessed' the character of the President. We shall return to this point in the conclusion, as it is central to our analysis. As regards public attitudes to these developments, it is worth stressing here that although $50 \%$ of French people polled at this time were in favour of sanctioning Assad (somehow), 64\% were against any military intervention by France (and this was even when it was widely assumed that the UK would be part of the coalition) (L'Express 31/8/13). In the political class, the degree of disfavour ran unusually from right to left (i.e. with the extreme right against intervention, the centre-right mainly against intervention, the centre against, and the centre-left and left (including the Greens) in favour, with the extreme left equally against). The range of opponents was therefore wide. Figures such as Marine Le Pen, the UMP leaders François Fillon and Jean-François Copé (although he initially supported), Dominique de Villepin (who had opposed the 2003 Iraq War in the UN), Centrists such as François Bayroux, all opposed the presidential initiative. Nathalie Kosciusko-Morizet remarked that Obama's virtual ignoring of Hollande was a humiliation. The leftist Jean-Luc Mélenchon was against, but even figures such as former President Giscard d'Estaing opposed, saying that 
such decisions should go - in the spirit of the European Defence and Security Policy - via the European Council. Hollande's stance should be seen in this light, namely, that it was against majority opinion.

One year earlier, on 20 August 2012, Obama had made a hostage to fortune - in fact he was trying to avoid intervention - when he spoke of chemical weapons use being the 'red line' that would trigger a US response. In December 2012, there were two 'small' chemical attacks reported in Homs and Alep. The UN was, then as later, unsure beyond a doubt who had been responsible. In April 2013, the French intelligence services said there had been two more attacks, acts of the Assad regime. In June 2013, the French encouraged the US to take a tougher line on chemical attacks. By 18 August, UN weapons inspectors arrived to examine three sites; and on 21 the east Damascus suburb of Ghouta suffered a major chemical attack. The attack took place (incidentally raising some doubts about the regime's guilt; why wait until the inspectors' arrival to use chemical weapons?), with an estimated 1429 victims, according to the US, 426 of whom were children. On 23 August, Ban Ki-moon, UN Secretary General spoke of a 'crime against humanity'. On 26 August, the Syrian government - who denied responsibility for the attacks - gave the green light for inspections.

Hollande's individual performances should also be seen in the context of the absence of alliances. There clearly was no real coalition (the US had support from Turkey and Saudi Arabia for obvious reasons, and briefly from Denmark). Neither the French nor the US had made the effort to build a coalition of the willing. Italy, Spain, Brazil wanted the UN Security Council to find a solution. Germany was against any action. Russia, China, obviously, but also Japan was opposed. Egypt and Algeria were against, Canada very reluctant, the Arab League extremely equivocal.

\section{Hollande's performance}


This was the context of François Hollande's three interventions over a period of just over two weeks (he had also said to Le Parisien newspaper on 26 that airstrikes (frappes aériennes) were a possibility). First, was the speech at the international Ambassadors Conference in Paris on 27 August where the word 'punish' was used; second, the interview in Le Monde on the 29, and third, a long interview on France's principal TV channel on 15 September. We shall concentrate on the first and third.iii Taken together, these three interventions framed the events from the French perspective, displayed moral outrage, personal commitment, and, in the case of the first two, a clear sense of imminent French attack.

In response to the chemical attack, Hollande's reaction was dramatic rhetorically, and retaliatory in tone. It was by far the most dramatic of all the Western powers, including the United States, and was very much the personal expression of President Hollande (Obama's 23 August 'grave concern' interview was much more downbeat). The Ambassadors meeting in Paris where Hollande made the speech was symbolic in itself as it was a meeting that was, by definition, an international one whose focus was France and its role in the world. Hollande's intervention was an immediate claim to authorship: 'I have consulted a great deal with the Americans and our European allies, and Arab League partners to gauge all sources of opinion, and tomorrow I will hold a Defence Council and Parliament will be informed without delay'. This quotation demonstrates how centrally Hollande was placing himself in the unfolding events.

The tone was was both outraged and martial, with the use of terms like 'firmness, abject act, ignominy, punish, response to the infamy of gassing innocent people'. (fermeté, acte abject, ignominie, riposte. It is also worth stressing that 'gazer des innocents' in French is evocative of Herod's biblical infanticide 'massacre of the innocents'). Hollande's outraged tone underscored 
the personal moral indignation of the speaker himself, as well as the notion of the imminence of violent retaliation/punishment. Both notions reflected the character of the speaker expressing 'just anger', and a consequent decision 'I have decided to increase our military support to the Syrian opposition'. He called the war cabinet meeting (Conseil de défense) the following day. In the subsequent Le Monde interview, he talked of the shocking act (acte effroyable) that was a crime against humanity. There is a large literature on the language of diplomacy and international relations (Donahue and Prosser 1997; Freeman 2010; Marks 2011), and in particular how vocabulary and rhetorical styles imply action in a performative Austinian sense; they are part of the action themselves. Let us identify the performative aspects of this first intervention. It was highly emotional, based upon moral outrage and a sense of international duty, implied imminent and violent retaliation-as-punishment, and was acutely personalised; and this latter not only in its emotional aspect, but also through the use of personal pronouns and the indication of François Hollande's personal command of the situation. It named Bashar Al-Assad several times, and the Syrian people he, Hollande, wished to protect, as if he were their personal champion, and Assad his own personal adversary. We might add that the general thrust of Hollande's rhetoric presented the clash as one between France and Syria - personified by the two leaders - as if there were no other players, even though in reality France would never have acted unilaterally. The rhetoric was that of France itself on the threshold of an avenging attack in punishment for the massacre of civilians with chemical weapons.

In between the first and third of Hollande's performances there was a whole series of developments which undermined Hollande's stance as a central protagonist. Let us briefly detail these. The American and Russian Navy began sending naval reinforcements to the Mediterranean, and the French aircraft carrier, The Charles de Gaulle, was put on stand-by in Toulon, as were French 
Rafale and Mirage fighter planes in the French base in Dubai. The following day, on 29 August, the UK Parliament voted down a call for armed intervention. Hollande immediately followed his Ambassadors speech with the Le Monde interview which reinforced the themes he had used at the Ambassadors meeting and his rhetorical stance, giving further weight to the idea of France's imminent action. However, immediately after Hollande's declarations and their tone of imminent action, on 31 August, President Obama said he - like the UK with its Parliament - would ask the US Congress for backing (given subsequent developments with the Russians this did not take place). The vote for this was to be taken over a week later, on 9 September (although the powerful Foreign Affairs Committee did give its backing on 6 September). But Obama's putting the vote to Congress (without a mention of France) brought the sequencing of Hollande's interventions to a sudden halt. It also had two further implications, both of which undermined Hollande's status by asserting it. First, he was the only leader involved not asking his parliament for its backing (only the UK was constitutionally obliged), and second, it made Hollande dependent, not upon his own parliament but upon the US Congress. It was as if Hollande had been freeze-framed. On 2 September Assad gave an interview to Le Figaro newspaper, as if mocking the French President (Holland reacted briefly to this interview on 3 September). Reflecting the emotionalism of his first interventions, two interesting 'defences' of the now silent President were, first, an emotional appeal on M6TV (1 September) by his partner, Valérie Trierveiler 'as a mother' (harrowing videos of the many victims of the Ghouta massacre were widely available on the internet); and, second, an equally emotional description of the dead a week later at a press conference by the Foreign Minister, Laurent Fabius (7 September). Hollande’s silence was also 'echoed' by some of the left's spokespeople who came forward sounding just as bellicose as Hollande had. David Assouline, Socialist Party spokesperson referred to the 'cowardice' ('une lacheté') of the international community if it did nothing. The 
leader of the French Socialist Party, Harlem Désir, spoke of an 'appeasement spirit' (esprit munichois), implying a Munich-like capitulation to totalitarianism (this is an even greater insult in France than the UK). All of these interventions, however, simply underscored the arrested rhetoric of the President and his initial rhetorical unilateralism.

Nine days after Hollande's near declaration of war against Syria, and a week after his self-imposed silence after the Le Monde interview of 29, all the major players - Obama, Cameron, Hollande, Merkel, Putin - met at the G20 summit (5-6 September) in Petersburg. It was only at the G20 that Hollande became active in attempting to gather support (and he took Fabius and Le Drian, Foreign and Defence ministers, with him). This was, however, too late for a proper coalition of ideas to be gathered, especially as everything depended now upon the US Congress vote. 12 countries eventually signed a common declaration condemning Syria, but military intervention was not even considered. France looked extremely isolated. Perhaps significantly, Obama was friendlier to other leaders (Cameron, Merkel) than to Hollande who, in footage of the G20 meeting, looked bemused and rather left out. The most significant 'event' of the summit however was Putin's (the host's) intransigent image and, paradoxically, his revelation during the summit (confirmed by Obama) that the two had had secret talks. This was an international public display of Hollande's lack of effectiveness upon developments. On 6 September (i.e. during the summit), Sarkozy (having shown 'leadership' on Libya) was widely reported in the French press, asserting that there was no leadership in this affair. On 9 September, after all the leaders had left the G20 in indecision and with no sense of diplomatic direction, Putin played his diplomatic ace: he publicly offered to bring the crisis to an end by offering to broker a solution, the securing and handing over of all Syria's chemical weapons. Damascus agreed immediately. 
From a sustained stance of imminent attack in August, President Hollande had moved into one of embarrassed silence, as France rapidly became perceived as an irrelevance, and was treated as such by the Russians, Syrians, and, in fact, the Americans. On 10 September, Obama made a TV broadcast (again with no mention of France) which was clearly an indication - in spite of references to crimes against humanity - that the strikes were very unlikely; they were not in the US' interests. On 12-14 September, John Kerry met and discussed the crisis with his Russian counterpart, Sergei Lavrov, in Geneva. They held a joint press conference (with Lavrov referring disparagingly to 'a few European capitals' (certaines capitales européennes) i.e. Paris). Kerry indicated he would meet Fabius in Paris on the Monday, i.e. after the Kerry/Lavrov meeting, once again publicly underscoring the fact that Hollande was not central to negotiations.

This was the moment (15 September) Hollande broke his silence and made his third major intervention, appearing on TF1 TV on the primetime p.m. news in an interview with Claire Chazal. The interview was a perfect illustration of Hollande's dilemma and approach: at this moment when, in Geneva, France's irrelevance was being thrown into relief, he persisted in, even amplified, his original rhetorical strategy of moral outrage and righteousness, acute personalism, and to which he added clairvoyance. He began by repeating that the situation in Syria was the gravest tragedy (La tragédie la plus grave), and cited again in detail the overall loss of life and suffering. He then justified the French position in the following way: 'As President of the Republic, the first question I had to deal with, not just in terms of my conscience, but in terms of the idea I have of what France is...' (La première question comme Président de la république que j’ai eue a régler, pas seulement autour de ma conscience mais de l'idée que je me suis fait de la France...'). This was not only the gathering of the whole issue once again into a contemplative act followed by a personal decision with international consequences, the last phrase is a direct evocation of 
the opening lines of de Gaulle’s Memoirs (De Gaulle 1954). Hollande not only stressed his own solitary decision-making, but linked it to apparent success (the US is mentioned here but almost as the junior partner): 'The pressure France exerted - not just France, the US - pressure that was sufficiently strong, convinced Russia, Putin, to act'. And we should note that it was 'the firmness shown by France in this affair' (C’est la fermeté montrée par la France dans cette affaire') which led to the diplomatic response by Putin. The word 'firmness' was used in the original Ambassadors speech. It is as if the same firmness shown to Assad was the decisive factor with Putin also; as if he were in a personal confrontation with each of them. He then went on, once again, as if he were the architect of not only the initial but also of the current events: 'What am I doing tomorrow? I will receive Foreign Minister Kerry... and the British Foreign Minister, and Laurent Fabius. And we shall draw up the next Security Council resolution'. The reality was that they were really simply ratifying the deal being elaborated over that very weekend between Lavrov and Kerry in Geneva. At three points in the interview, he restated this idea that his original intention had the intended result, namely, that the threat of attack was in order (pour faire... évoluer) to effect a change in Russian diplomacy. The truth was that France was taken by surpise by the Russian initiative, just as it had been by Obama’s decision to consult the US Congress.

Hollande also deployed a stream of first person pronouns linked to verbs of intention and action - I think, I wanted, I refuse, me, I want, I have to say, I understand, I have, myself... and many more (Je pense, J'ai voulu, Je m'y refuse, Moi, je veux, Je dois dire, Je les comprends, J'ai d'ailleurs, moi meme). He ended his discussion of Syria with a claim both to unfettered freedom of action and to great wisdom, and an affirmation of the pretensions of the French Fifth Republic presidency: 'As for me, I do not rely upon any country, whatsoever. Not for Mali, not for Syria; I commit France or I don't commit 
France when I consider that our essential interests are at stake' (Moi je ne dépends pas de quelque pays que ce soit. Pas pour le Mali, pas pour la Syrie, j'engage la France ou je ne l'engage pas quand je considère que ce sont nos intérêts essentiels qui sont en cause). At one level, this breathtakingly autocratic statement counters his argument throughout the period that it was personal, moral outrage in the name of humanity that prompted him; but it is also one of the clearest statements of what the institution of the French presidency would have itself: Gaullist, unfettered, and quintessentially personal. In terms of the efficacy of his approach, after every public intervention François Hollande made since he became President his ratings fell. This interview was no exception. This raises the question of the relationship of Hollande's selfdepiction to opinion. We shall return to this in the conclusion.

In the course of the following days, as the resolution was taken through the UN, the French attempted to have a reference to responsibility for war crimes involved in the draft. On 19 September, Vladimir Putin threatened to end the process if Syria were threatened in this way. A new one was elaborated with Laurent Fabius taking it to Moscow personally for the Russians to agree it. This was done on 27 September. It included Syria's agreement to sign up to the Chemical Weapons Convention (from 14 October 2013). Assad claimed a victory for Syria for its crisis diplomacy, and gave an interview to Rai News (Italy, on 24 September). He said the Europeans were disqualified from helping (meaning the French), and to Der Spiegel (7 October) where he invited Germany to work with Syria to find a solution. On 14 October, to a major Lebanese daily he said that he - not the Organisation for the Prohibition of Chemical Weapons - should have been awarded the Nobel Peace Prize. It was estimated that there were 1000 tonnes of chemical weapons in Syria in approximately 45 sites. International attention then turned away from Syria to Iran with, once again, the French playing no significant role. In October, the 
inspectors arrived in Syria to begin their work. Geneva 2 was set for 22 January $2014 .^{\text {iv }}$

\section{Conclusion}

In conclusion, we can make six points relating to Hollande's rhetorical performance and five to our theorisation of the French presidency.

A first point is to note the personal, determined and 'crusading' nature of Hollande's position up until Obama's decision to consult Congress, and the image of confusion and irrelevant isolation afterwards. Second, in the period from the end of August to the end of September, François Hollande suffered three humiliations related to his initial stance. The first was Obama's 31 August declaration (immediately after the UK Parliament vote) that he was seeking Congress' approval. The French were not informed of this decision, nor referred to in the speech. Because of Hollande's unilateral - rhetorically unilateral as it were - bellicosity of the 27 August, he now - immediately - seemed an irrelevance. As early as 31 August, it was clear that Obama was seeking a reason not to attack Syria, a fact that escaped the French. The second humiliation was Obama's second broadcast on 10 September where he began his speech as if maintaining his previous tone of outrage and threat: chemical attack was a crime against humanity, but went on to say that the US was not threatened and, therefore, no attack would take place. This was immediately followed by the Putin/Lavrov initiative. This sent the French back to the UN lobbying vainly, and as if unilaterally, for support from countries now all awaiting the outcome of negotiations between the US and Russia. The third was the elaboration of the Russia-US deal from 9 September onwards, which was essentially an agreement drawn up between Lavrov and Kerry, with France participating in the same minor degree as Germany, the UK, and even Syria.These developments contrasted strongly with France's continuing 
rhetoric. The 15 September was the date of Hollande's TV appearance with Clare Chazal where, at the moment France's isolation was being confirmed, the President maintained the tone of righteousness and self-importance we identified. Our third performance-related point was that the cognitive dissonance now consistently ascribed to François Hollande in domestic affairs was now confirmed in international diplomacy, i.e. the tone of France's selfimportance, and the President's bold, morally inspired activism on the international stage was thrown into relief as almost narcissistic self-delusion. From the 27 September, Syria just fell off the international agenda, to be replaced by the domestic but equally humiliating 'Leonarda Affair'. 'Fourth, while the UK and then US sought legitimation through democracy, the French President seemed able to go to war without democratic constraint. The result, however, was that the authority of the French presidency was damaged and the Fifth Republic altered because, in fact, it was clear that Hollande could not do as he wanted. The decision to intervene in the Central African Republic in December 2013 should also be seen in this context. Fifth, this was the first time for more than two decades that the French had willingly acted alongside the US, and yet had gained no diplomatic advantage, in fact the opposite. In his Le Monde interview, Hollande declared 'each country is sovereign to participate or not in an operation'. Only, however, at the level of the UK's right-of-refusal, as it were, was this demonstrated as being true. At the level of action, given subsequent developments (and even Obama realised this), this was patently not the case: France was frozen into highly visible diplomatic stasis by the UK and US decisions to, respectively, withdraw and consult. The French events demonstrated that the all-powerful French President who, unlike the UK Prime Minister, can go to war on the President's whim, had, in this case, no power at all. 
Sixth, in contrast to the misreading of the situation and miscalculation of the strategy to adopt by President Hollande, the world was shown a kind of pirouette performance by President Putin who waited until the surly G20 was over, and Obama awaited his fate from the US Congress vote, then offered to the Americans alone, a solution to the crisis (which, of course, would have little effect upon the brutality and course of the war, while removing Syria from the threat of attack). Obama's difficulties and Hollande's confusion added to the idea of Putin's diplomatic mastery. A lot of this is illusory, but the personalisation of these exchanges had major effects with 'Russia' regaining a kind of Soviet or Tsarist standing, and Putin the added image of a Russian chess master. ${ }^{\text {vi }}$ Throughout September, all the central negotiations were bi-lateral, and demonstrated what had always been the case, that Russia had to be part of the solution, with a notional further solution offered in the promise of a Geneva 2 in January 2014. All this time, the French were disparaged, by Putin through no reference to France in his New York Times article, Lavrov through his disparaging reference to 'certain European capitals' (meaning Paris), through Assad's first Figaro interview (2 September) which both threatened and criticised Europe (meaning France), then the Der Spiegel interview which flattered Germany as potentially contributing (i.e. not France) to a diplomatic resolution, and through, it must be said, the Americans' insensitive ignoring of the French, their only real support. Kerry's declaration of historical alliance was a myth, now as much as it had ever been. This brings us to the central question of why all this happened and back to our theoretical considerations.

Much of this article has identified a series of personal political miscalculations, but the real issue is not François Hollande but the Fifth Republic. We have seen in our theory section that the 'self' was brought centre-stage by the Republic's founder, Charles de Gaulle. The driving institution of the Fifth Republic is the presidency, and the condition of its performance is the deployment of 
presidential 'character' and its performed rhetorical relationship to an imagined France. The institution of the presidency obliges the President to (attempt to) behave in a particular way; namely, to deploy a 'self', a 'character' with an as if unrestricted freedom to act. The first problem for François Hollande was that from the outset of his presidency, and by the autumn of 2013, 18 months into his presidency, his popularity ratings in the polls were so low (20\% and falling) that even his legitimacy was in question. The one moment of respite (and it was a moment) for his falling popularity had been the Mali intervention of January 2013. We should see the Syria fiasco in that context, ${ }^{\mathrm{vii}}$ as an attempt to reassert presidential 'character'. And the character deployed/performed was that of a decisive, intransigent, man of action (all the characteristics that poll respondents said he lacked); and a man of courage, moral principle, and insightfulness, all the characteristics required of an inspirational leader. Hence the tone of Hollande's discourse and rhetoric, hence the will to firmness (fermeté) and the will to 'punish' the wicked and protect 'les innocents'; hence too the, by 15 September, cognitively dissonant self-referentiality, and reference to himself as the architect of change in the Syrian crisis.

Regarding the contemporary UK literature on rhetoric and performance we can make four points. First, the nature of the relationship between leader and audience (or imagined audience) differs according to the institutions and culture. Finlayson demonstrated that Tony Blair's leadership image deployed a relationship to the British public akin to a populism. In the French presidential case, we have seen that the relationship is less direct. The main performed relationship of the French President is one of a privileged personal one to an imagined France, and the relationship to the public is the public 'display' of that privileged relationship. All of Hollande's focus and self-justification proceed from this. All French Presidents, even de Gaulle, have deployed a populist style, but it vies with and is arguably subordinate to this other imagined relationship, 
more apparent in the UK for example only in moments of perceived crisis. Second, if we consider Martin's emphasis on the importance of rhetorical context, argument and effect, in the French case we have examined here, the driving need to display the self, 'le moi', informs the rhetoric acutely. In Hollande's case, he moved from from an initial attempt to diminish the display of 'character' to a concerted, yet not very successful, self-assertion. Third, celebrity politics literature and research (e.g. Corner, Street, Wheeler), is highly relevant to our approach. In the French case, the politics of celebrity heightens the tension and blurs the relationship that exists between the 'King's Two Bodies' (Manow 2010), and this in part because the performing President is 'on stage' all the time. This has been exacerbated by the new (from 2002) five-year presidential term (Gaffney 2012) which has significantly increased the 'pace' of politics. Celebrity politics also means that the iconic and kinetic aspects of presidential performance (Ambassadors meeting, the setting of performance, e.g. Le Monde, the TV studio or a speech or interview televised at the Elysée Palace, at a podium with tricolore and/or European flag etc) all 'frame' performance. Drake and Higgins stress this frame, celebrity politics as a process. Our analysis here also throws into relief Wheeler's emphasis upon agency within process, in this case agency as bad performance.

Our central finding, however, is that studying political performance is a helpful way of analysing the political process, especially in the French case; performance is central to the process because of its rhetorical relationship to both institutional and cultural frameworks and the centrality of these two frameworks in the French Fifth Republic.

\footnotetext{
${ }^{\mathrm{i}}$ These types of journal still dominate but are changing. Mots has a research interest in rhetoric. There is also a renewal of interest, e.g. via the semiology of political communication (Bertrand 2007; Mayaffre 2012); and recently, based at Sciences-Po Paris, the new rhetoric group, Aequinox.
} 
ii France reintegrated into the command structure of NATO in March 2009 (by Sarkozy and opposed by Hollande). It had also successfully intervened, leading the NATO-backed coalition of the UK, US and France in Libya in March 2011. It intervened, again successfully, in Mali and with international approval, if not help, in January 2013. These, however, were recent developments in a troubled history of French foreign policy, largely conditioned, driven even, by France's highly problematic relationship with the United States and its foreign policy. France had joined the international coalition in 1991 in the first Gulf War, but it was the second Gulf War of 2003 that most recently defined the very poor relations between the US and France (Gaffney 2004).

iii The Le Monde interview occurred at exactly the same moment as the UK parliamentary vote against military involvement, so it was - especially given the international nature of the newspaper - a public act of Hollande's personal resolve and courage. On 28 August, much was also made of the army's preparedness for battle (awaiting only the President's order). On the same day, Hollande met the leader of the Syrian opposition. Each of these created the sense of military action within the following days.

iv This international conference took place but was inconsequential. On 13/12/13 the UN inspectors report was published. It established use of chemical weapons in at least four cases, but still was equivocal regarding responsibility.

v The 'Leonarda Affair' taking place at the same time concerned the treatment of a Kosovan family being deported from France. The public involvement of Hollande in this at the same time as Syria was equally humiliating for the President as he handled it even less well. These two issues, one 'high' ane 'low', are a stark illustration of the President's involvement in all aspects of politics and policy, from a minor Home Affairs issue to France on the international stage.

${ }^{v i}$ Putin's failure to rein in separatists in Ukraine, particularly in the aftermath of the shooting down of flight MH17 in July 2014, severely affected this image.

vii There is also a 'systemic' aspect to this issue, namely, that Hollande became President almost accidentally (after Dominique Strauss-Kahn failed to enter the party primaries). In this way, Hollande became President of the Republic and Head of the Armed Forces without any governmental experience, let alone foreign policy or diplomatic experience.

\section{References}

Austin, J. L. (1975) How to do Things with Words. Oxford: Oxford University Press.

Barthes, R. (1957) Mythologies. Paris: Seuil.

Bell, D.S. and Gaffney, J. (eds) (2013) The Presidents of the French Fifth Republic. Basingstoke: Palgrave Macmillan.

Berstein, S. (2001) Histoire du gaullisme. Paris: Perrin.

Bertrand, D. et al (2007) Parler pour gagner. Paris: Presses de Sciences-Po.

Cerny, P.G. (1980) The Politics of Grandeur: Ideological Aspects of de Gaulle's Foreign Policy. Cambridge: Cambridge University Press.

Chalaby, J. K. (2002) The de Gaulle Presidency and the Media: Statism and Public Communications. Basingstoke: Palgrave.

Corner, J. (2000) Mediated persona and political culture: Dimensions of structure and process. European Journal of Cultural Studies, 3, 3, pp. 386-402.

Cotteret J.-M. (1969) Recherche sur le vocabulaire du général de Gaulle. Paris: A. Colin.

De Gaulle, C. (1954) Mémoires, Vol. 1. Paris: Plon.

Donahue, R.T. and Prosser, M.H (1997) Diplomatic Discourse: International Conflict at the United Nations. Greenwich: Ablex Publishing Corp. 
Drake, P. \& Higgins, M. (2012) Lights, Camera, Election: Celebrity, Performance and the 2010 UK General Election Leadership Debates. British Journal of Politics and International Relations, 14, 3, pp. 375-391.

Duhamel, O. (1993) Le pouvoir politique en France. Paris: Seuil.

Elgie, R. (2011) Semi-Presidentialism: Sub-Types And Democratic Performance. Oxford: Oxford University Press.

Fairclough, N. (2014) Language and Power. London: Longman.

Finlayson, A. (2002) Elements of the Blairite Image of Leadership. Parliamentary Affairs, 55, 3, pp. 586-599.

Freeman, C.W. (2010) Diplomat’s Dictionary. Washington: Institute of Peace Press.

Gaffney, J. (2004) Highly Emotional States: French-US Relations and the Iraq War, Journal of European Security, 13, 3, pp. 247-272.

Gaffney, J. (2012) Political Leadership in France: From Charles de Gaulle to Nicolas Sarkozy. Basingstoke: Palgrave Macmillan.

Gaffney, J. (2014) Performative Political Leadership in t' Hart, P. and Rhodes, R. (eds.) The Oxford Handbook of Political Leadership. Oxford: Oxford University Press.

Gaffney, J. (2015) France in the Hollande Presidency: The Unhappy Republic. Basingstoke: Palgrave.

Gaffney, J. and Lahel, A. (2013a) The Morphology of the Labour Party's One Nation Narrative: Story, Plot and Authorship, The Political Quarterly, 84, 3, pp. 330-341.

Gaffney, J. and Lahel, A. (2013b) Political Performance and Leadership Persona: The UK Labour Party Conference of 2012, Government and Opposition, 48, 3, pp. 1-25.

Gaïti, B. (1998) De Gaulle, prophète de la cinquième république. Paris: Presses de Sciences Po.

Garrigues, J. (2012) Les hommes providentiels. Paris: Seuil.

Hall Jamieson, K. (1988) Eloquence in an Electronic Age: The Transformation of Political Speechmaking. Oxford: Oxford University Press.

Helms, L. (2012) (ed) Poor Leadership and Bad Governance: Reassessing Presidents and Prime Ministers in North America, Europe and Japan. Cheltenham: Edward Elgar.

Hoffman, S. (1994) The Foreign Policy of Charles de Gaulle. Princeton: Princeton University Press. 
Kohrs Campbell, K. and Hall Jamieson, K. (2010) Presidents Creating the Presidency: Deeds Done in Words. Chicago: University of Chicago Press.

Labbé, D. (1977) Le discours communiste. Paris: FNSP.

Labbé, D. (1990) Le vocabulaire de François Mitterrand. Paris: FNSP.

Manow, P. (2010) In the King’s Shadow. Cambridge: Polity.

Marks, M.P. (2011) Metaphors in International Relations. Basingstoke: Palgrave.

Martin, J. (2013) Politics and Rhetoric. London: Routledge

Mayaffre, D. (2012) Le discours présidentiel sous la Cinquième République. Paris: Presses de Sciences-Po.

Saussure, F. de (1995 (1916)) Course in General Linguistics. New York: Columbia University Press.

Street, J. (2004) Celebrity politicians: Popular culture and political representation. British Journal of Politics and International Relations, 6, 4, pp. 435-452.

Street, J. (2012) Do Celebrity Politics and Celebrity Politicians Matter? British Journal of Politics and International Relations, 14, 3, pp. 346-356.

van Dijk, T.A. (2008) Discourse and Context: A Sociocognitive Approach. Cambridge: Cambridge University Press.

Wheeler, M. (2012) The Democratic Worth of Celebrity Politics in an Era of Late Modernity. British Journal of Politics and International Relations, 14, 3, pp. 407-422.

Wodak, R. (2009) The Discourse of Politics in Action: Politics as Usual. Basingstoke: Palgrave. 